\title{
On the need to consider the lithological composition of overburden rocks in the design of waste water treatment plants at open pit mines
}

\author{
Elena Murko ${ }^{1,3^{*}}$, Juraj Janočko², Eugene Makridinn ${ }^{4}$, and Martin Kapko ${ }^{2}$ \\ ${ }^{1}$ T.F. Gorbachev Kuzbass State Technical University, Open Pit Mining Department, 650000 \\ Kemerovo, 28 Vesennyaya st., Russian Federation \\ ${ }^{2}$ Technical University of Kosice, Faculty BERG, Letná 9, 04200 Kosice, Slovak Republic \\ ${ }^{3}$ Prokopyevsk branch of T.F. Gorbachev Kuzbass State Technical University, 653039 Prokopyevsk, \\ 19a Nogradskaya st., Russian Federation \\ ${ }^{4}$ JSC “SUEK-Kuzbass”, Surface Mining Office, 652507 Leninsk-Kuznetsky, 1 Vasil'eva st., Russian \\ Federation
}

\begin{abstract}
The issue of wastewater treatment in open-pit mining of mineral deposits is associated with great difficulties. Due to the constant tightening of requirements for the quality of discharged wastewater, its treatment in the sedimentation reservoirs and clarification ponds does not ensure the achievement of MPC values; in addition, these treatment facilities occupy significant areas of land. It should also be noted that the open-pit mines, as a rule, have several water outlets remote from each other, besides changing their location as the development of mining operations proceeds. For example, OJSC "UK "Kuzbassrazrezugol" has more than 30 places of water use, taking into account that the company structure includes 7 open-pit mines. In the article some results of analyses of pit waste water before and after its treatment in artificial filtering massifs at the mining enterprises of Kuzbass are presented. Preliminary dependences of changes in pollutant impurities in quarry water on different composition of coal waste have been established.
\end{abstract}

\section{Introduction}

Currently, a significant part of the existing and prospective $[4,6,7]$ Kuzbass open-pit mines treat wastewater in artificial filtering massifs from coal waste [9, 11, 14, 19, 21, 23]. Given that the trend of growth in the rate of surface coal mining in Kuzbass persists [17, 30, 34-39], and as a consequence, the volume of water discharged by mines will inevitably increase, further research is needed to improve the environmental safety of mining operations. Industrial testing of wastewater treatment by filtration in overburden massifs was conducted at treatment facilities built according to recommendations of the authors, at enterprises of OJSC "UK Kuzbassrazrezugol", hereinafter referred to as "site 1" and "site 2".

${ }^{*}$ Corresponding author: zhev.httte@,kuzstu.ru 
The research consisted in taking and analyzing samples of waste water before and after treatment in the filtering massifs. The filter arrays were constructed from overburden mined at the corresponding open pit.

\section{Methods}

The sediments of the Kuznetsk coal basin (Kuzbass) are represented mainly by sandstones, mudstones, and siltstones. A large number of sediments are carbonized. Since these overburden rocks are widely used for the construction of artificial filtering massifs for the treatment of open pit wastewater, it is necessary to understand the influence of their lithological constitution on the quality of treatment [31-33]. The mineral and microstructural composition of rocks has a rather strong influence on the adsorption properties of rocks [1-3, $5,8,10,12,13)$. For example, siltstone on carbonate cement will have a more pronounced ability to absorb petroleum products than hard sandstone on siliceous cement $[15,16,40]$. This is due to the significant specific surface area and the more porous structure of the argillite cement compared to the mentioned sandstone [20, 22, 24-29].

Since the sedimentary strata within Kuzbass are represented by different lithological formations, the filtering capacities of the filtering massifs at different mining enterprises will also be different.

In order to establish the influence of the lithological composition of rocks on their filtration capacity, the rocks of different series of Kuzbass were studied at two different enterprises. Mass spectrometry and chemical analysis methods were used to determine the quality of filtered water. Water samples were taken both before and after filtration.

\section{Results}

The results of studies of changes in the composition and properties of wastewater during filtration in the overburden are presented in Table 1. The obtained results of industrial effluent treatment were compared; for the purpose of information protection [18] the experimental sites are marked as "site 1 " and "site 2 ".

It was established that the $\mathrm{pH}$ value decreases, the maximum value is 9.07; the minimum value is 7.73. It is known that the concentration of hydrogen ions $(\mathrm{pH})$ is due to the ratio of concentrations of free carbon dioxide, bicarbonate ions, the content of humic substances, basic carbonates and hydroxides. In our case, carbonates change similarly to $\mathrm{pH}$.

Sulfates increase after the water passes through the filter at "site 2 " and decrease at the "site 1" open pit. Similar changes can be observed for chlorates, nitrites, nitrates and carbonates. It can be assumed that as a result of prolonged contact (up to 7-8 hours) of industrial effluents with the carbonaceous filter massifs, processes of leaching (washout) occur, which lead to a change in the salt composition.

For example, sulfate content in open pit "section 2" after treatment increases by 4 times, chloride-ion by 2 times, nitrate-ion by 2 times.

The increase in mineral salts when passing the filter arrays is found in three of the four treatment plants. For example, in site 2 the dry residue increased 2,5 times, while in site 1 the dry residue decreased from $400 \mathrm{mg} / \mathrm{l}$ to $300 \mathrm{mg} / \mathrm{l}$, the content of anions and cations respectively from $311 \mathrm{mg} / \mathrm{l}$ to $254,5 \mathrm{mg} / \mathrm{l}$ and from $127,87 \mathrm{mg} / \mathrm{l}$ to $93,88 \mathrm{mg} / \mathrm{l}$.

To explain these changes, it is necessary to investigate the processes that accompany filtration through the array.

The oxidation index in all cases decreases by $0.48 ; 0.32 ; 0.48 ; 0.16 \mathrm{mg} / \mathrm{l}$. It can be assumed that the amount of substances oxidized by strong oxidizing agents (potassium permanganate) decreases after filtration in all cases. 
At all filters there is an increase of total hardness by $0,5 \div 20,75 \mathrm{mg}$-eq/l. Concentration of cations of divalent alkaline earth metals, primarily calcium and magnesium, can increase in the filtrate due to carbon dioxide, carbonate minerals or as a result of biochemical processes occurring in wetted coal-rock massifs. The content of dissolved calcium salts in water and changes in their concentration depend in vivo on the equilibrium of carbonic salts and carbon dioxide. In very hard waters, the release of calcium carbonate can occur when carbon dioxide equilibrium is disturbed and the carbon concentration decreases.

Table 1. Changes in water composition and properties during filtration in overburden rock.

\begin{tabular}{|c|c|c|c|c|c|c|c|c|}
\hline open pit & $\begin{array}{l}\text { measuring } \\
\text { unit }\end{array}$ & K & \multicolumn{2}{|c|}{$\mathrm{Na}$} & \multicolumn{2}{|c|}{$\mathrm{Ca}$} & $\mathrm{Mg}$ & $\mathrm{NH}_{4}$ \\
\hline $\begin{array}{l}\text { site } 1 \text { (before } \\
\text { treatment) }\end{array}$ & $\mathrm{mg} / \mathrm{l}$ & 3.3 & \multicolumn{2}{|c|}{33.81} & \multicolumn{2}{|c|}{72.14} & 42.56 & 0.3 \\
\hline $\begin{array}{c}\text { site } 1 \text { (after } \\
\text { treatment) }\end{array}$ & $\mathrm{mg} / \mathrm{l}$ & 0.92 & \multicolumn{2}{|c|}{$\begin{array}{c}\text { not } \\
\text { detected }\end{array}$} & \multicolumn{2}{|c|}{30.06} & 74.18 & 0.28 \\
\hline $\begin{array}{c}\text { site } 2 \text { (before } \\
\text { treatment) }\end{array}$ & $\mathrm{mg} / \mathrm{l}$ & 3.2 & \multicolumn{2}{|c|}{72.91} & \multicolumn{2}{|c|}{52.1} & 92.24 & 0.34 \\
\hline $\begin{array}{l}\text { site } 2 \text { (after } \\
\text { treatment) }\end{array}$ & $\mathrm{mg} / \mathrm{l}$ & 7.0 & \multicolumn{2}{|c|}{27.6} & \multicolumn{2}{|c|}{54.11} & 345.34 & 0.6 \\
\hline open pit & $\begin{array}{c}\text { measuring } \\
\text { unit }\end{array}$ & $\mathrm{CO}_{3}$ & $\mathrm{HCO}_{3}$ & \multicolumn{2}{|c|}{$\mathrm{SO}_{4}$} & $\mathrm{Cl}$ & $\mathrm{NO}_{2}$ & $\mathrm{NO}_{3}$ \\
\hline $\begin{array}{c}\text { site } 1 \text { (before } \\
\text { treatment) }\end{array}$ & $\mathrm{mg} / \mathrm{l}$ & 45.0 & 280.6 & \multicolumn{2}{|c|}{73.25} & 33.18 & 140 & 6.2 \\
\hline $\begin{array}{l}\text { site } 1 \text { (after } \\
\text { treatment) }\end{array}$ & $\mathrm{mg} / \mathrm{l}$ & 18.0 & 219.6 & \multicolumn{2}{|c|}{82.30} & 57.72 & 0.01 & 2.5 \\
\hline $\begin{array}{c}\text { site } 2 \text { (before } \\
\text { treatment) }\end{array}$ & $\mathrm{mg} / \mathrm{l}$ & 18.0 & 170.8 & \multicolumn{2}{|c|}{342.4} & 95.45 & 0.01 & 24.8 \\
\hline $\begin{array}{l}\text { site } 2 \text { (after } \\
\text { treatment) }\end{array}$ & $\mathrm{mg} / \mathrm{l}$ & 12.0 & 134.2 & \multicolumn{2}{|c|}{1326.0} & 52.72 & 1.98 & 47.1 \\
\hline
\end{tabular}

Microelement analysis of industrial waste water was carried out for specific pollutants in the industrial waste water of the quarries. The analyses showed that manganese is usually present in water in dissolved form as divalent ions, and in undissolved form as hydroxides of higher oxidation degrees. The table shows that at low initial concentrations, $10^{-3} \div 10^{-2} \mathrm{mg} / \mathrm{l}$, the amount of manganese increases insignificantly. At initial concentration of manganese $0,42 \mathrm{mg} / \mathrm{l}$ (site 1) after purification its amount decreases to $0,27 \mathrm{mg} / \mathrm{l}$. At low concentrations $\left(10^{-2} \div 10^{-4} \mathrm{mg} / \mathrm{l}\right)$ the amounts of such microcomponents as arsenic, selenium and fluorine remain constant. Decrease of lead concentration by $10^{-3} \mathrm{mg} / \mathrm{l}$ and increase of strontium concentration by $0.4-1.1 \mathrm{mg} / \mathrm{l}$ were noted.

The data obtained under laboratory conditions confirm our conclusions about the possibility to influence the micro- and macro-component composition of industrial effluents as a result of their filtration through a massif of coal waste.

Analysis of changes in the content of suspended solids during filtration, along with a description of its mechanism, is considered in detail earlier and is not given in this article.

The composition of mine water after soaking in it various samples of sandstones and siltstones showed that the amount of macroelements can increase, decrease or remain constant depending on the composition of the rock. For example, the amount of calcium cations decreases in all samples, while the amount of magnesium increases in three samples and decreases in one siltstone. The amount of iron is constant in three samples $(0.5 \mathrm{mg} / \mathrm{L})$, and in the fourth (siltstone) increased to $2 \mathrm{mg} / \mathrm{L}$. The dependence of the macroelement 
composition of water on the different composition of carbonaceous wastes (siltstones, sandstones) can also be traced on other indicators: chlorides, nitrates, carbonates, ammonia, hardness and acidity.

Concentrations of strontium, barium, and titanium decrease in all samples. Concentrations of aluminum, iron, silicon, copper, nickel, zirconium may decrease or increase in relation to the initial values.

For subsequent studies, it was necessary to make a lithological composition of the coalbearing sediments of the Kuzbass.

The coal-bearing stratum of the Kuznetsk Basin is represented predominantly by the upper part of the Carboniferous system and the entire Permian system. The deposits of these systems consist of such terrigenous petrographic varieties as conglomerates, sandstones, siltstones, mudstones, and organogenic deposits in the form of hard coal beds. The largest portion is represented by sandstones (31.9\%), siltstones ( $44.3 \%)$, and mudstones $(16.7 \%)$. Conglomerates with gravelites, carbonaceous rocks, coal, and carbonate concretions account for the rest, Table 2 .

Table 2. Composition of the Upper Paleozoic coal-bearing sediments of the Kuznetsk Basin

\begin{tabular}{|c|c|c|c|c|c|}
\hline \multirow[b]{2}{*}{ Formation } & \multicolumn{5}{|c|}{ Ratio of lithotypes, \% } \\
\hline & $\begin{array}{c}\text { Conglomerate, } \\
\text { gravelite, } \\
\text { carbonate } \\
\text { concretions }\end{array}$ & Sandstone & Siltstone & Mudstone & $\begin{array}{c}\text { Carbonaceous } \\
\text { rocks }\end{array}$ \\
\hline \multicolumn{6}{|c|}{ Kolchuginsky series $\left(\mathrm{P}_{2}-\mathrm{P}_{3}\right)$} \\
\hline All formations & 3.5 & 26.0 & 49.6 & 20.8 & 0.1 \\
\hline \multicolumn{6}{|c|}{ Yerunakovskaya subseries } \\
\hline All formations & 5.0 & 26.2 & 47.8 & 20.9 & 0.1 \\
\hline Tailugan & 4.8 & 26.7 & 49.8 & 18.6 & 0.1 \\
\hline Gramoteinskaya & 6.1 & 25.9 & 51.7 & 16.2 & 0.1 \\
\hline Leninskaya & 4.7 & 25.9 & 43.4 & 25.9 & 0.1 \\
\hline \multicolumn{6}{|c|}{ Ilyinskaya subseries } \\
\hline All formations & 1.8 & 25.8 & 51.2 & 21.1 & 0.1 \\
\hline Uskatskaya & 3.5 & 20.6 & 51.4 & 24.4 & 0.1 \\
\hline $\begin{array}{l}\text { Kazankovo- } \\
\text { Markinskaya }\end{array}$ & 1.0 & 28.2 & 51.2 & 19.5 & 0.1 \\
\hline \multicolumn{6}{|c|}{ Kuznetsk subseries } \\
\hline All formations & 3.4 & 26.1 & 50.5 & 20.0 & - \\
\hline \multicolumn{6}{|c|}{ Balakhonskaya series $\left(\mathrm{C}_{1}-\mathrm{P}_{1}\right)$} \\
\hline All formations & 1.4 & 45.9 & 39.3 & 11.3 & 2.1 \\
\hline \multicolumn{6}{|c|}{ Upper Balakhon subseries $\left(\mathrm{P}_{1}\right)$} \\
\hline All formations & 1.3 & 53.5 & 37.2 & 5.5 & 2.5 \\
\hline Kemerovskaya & 1.1 & 55.9 & 31.1 & 9.0 & 2.9 \\
\hline Ishanovskaya & 0.6 & 53.2 & 41.9 & 2.0 & 2.3 \\
\hline Intermediate & 1.8 & 52.4 & 38.2 & 5.1 & 2.5 \\
\hline \multicolumn{6}{|c|}{ Lower Balakhon subseries $\left(\mathrm{C}_{2-3}\right)$} \\
\hline All formations & 1.6 & 39.4 & 39.1 & 17.0 & 2.9 \\
\hline Alykaevskaya & 1.3 & 40.9 & 35.0 & 19.9 & 2.9 \\
\hline Mazurovskaya & 1.9 & 37.8 & 43.8 & 13.7 & 2.8 \\
\hline
\end{tabular}


The analysis of Table 2 clearly shows that the Upper Permian deposits of $\mathrm{P}_{2}$ (Kolchuginsky series) consist of $67.4 \%$ siltstones and mudstones (clayey varieties) and sandstones occupy only $24.9 \%$, whereas in the Lower Permian deposits of $\mathrm{P}_{1}$ sandstones prevail (51\%) and siltstones and mudstones account for $35-43 \%$.

Sandstones are characterized by higher strength, less tendency to softening and soaking, and greater water permeability.

\section{Conclusion}

Thus, more favorable conditions for construction of artificial filtering massifs for treatment of waste water exist at coal enterprises that mining coal seams of the Upper Balakhon subseries' formations of the Balakhon series (Kemerovskaya, Ishanovskaya, Intermediate formations). At the coal mines operating in the coal-bearing sediments of the Kolchuginsky series, it is advisable to make a selective dumping of overburden into the filtering massifs to ensure the predominance of sandstones in them.

\section{References}

1. J.G. Tundisi, T. Matsumura-Tundisi, V.S. Ciminelli, F.A. Barbosa, Proc. IAHS, 366, $75(2015)$

2. C. Potera, Environmental Health Perspectives, 108(10) (2000)

3. S. Homaeigohar, Water, 12, 1507 (2020)

4. S. Markov, V. Martyanov, E. Preis, A. Abay, E3S Web of Conf., 21, 01021 (2017)

5. S.I. Zeeman, P. Weinstein, E. Fearnley, C. Skelly, E.N. Naumova, J.S. Jagai, D. Castronovo, J. McEntee, M. Koch, S. Hamner, T. Ford, Environmental Tracking For Public Health Surveillance (International Society for Photogrammetry and Remote Sensing (ISPRS) Book Series, a Balkema Publishers), 11, 87 (2013)

6. Y. Lesin, V. Gogolin, E. Murko, S. Markov, J. Kretschmann, E3S Web of Conf., 41, 01039 (2018)

7. V.A. Gogolin, Yu.V. Lesin, O.I. Litvin, Ya.O. Litvin, Journal of Mining and Geotechnical Engineering, 1(12), 69 (2021)

8. A. Manzardo, A. Mazzi, L. Rettore, A. Scipioni, J Cleaner Prod, 70, 251 (2014)

9. M. Tyulenev, Yu. Lesin, E. Tyuleneva, E. Murko, E3S Web of Conf., 15, 02003 (2017)

10. F. R. Klaus, S. Gekle, R. R. Netz, J. Phys. Chem. A, 118(50), 11667 (2014)

11. E. V. Makridin, M. A. Tyulenev, S.O. Markov, Y. V. Lesin, E. V. Murko, Mining Inf and Analytical Bulletin, 12, 89 (2020)

12. J.P.M. Lima, S.L.S. Rollemberg, Rev. Virtual Quim., 12(2), 447 (2020)

13. A.A. El-Moneim, A. A. Hassan, S.A. El-Fotouh, A. El-Saadi, Int J Eng Adv Tech (IJEAT), 9(3), (2020)

14. M. Tyulenev, S. Markov, E. Makridin, Y. Lesin, V. Gogolin, E3S Web of Conf., 105, 02022 (2019)

15. R. Eliassen, J Amer Water Works Assoc, 33(5), 926 (1941)

16. P. Dillon, Ground Water, 47(4), 492 (2009)

17. V.L. Martyanov, J Mining Geotech Eng, 1, 35 (2018)

18. M. Cehlár, P. Rybár, J. Mihók, J. Engel, J Mining Geotech Eng, 1, 4 (2020)

19. M. Tyulenev, A. Khoreshok, E. Garina, O. Litvin, Y. Litvin, E. Maliukhina, IOP Conference Series: Earth and Environmental Science, 012035 (2017)

20. I. Gehrke, A. Geiser, A. Somborn-Schulz, Nanotech Sci App, 8, 1 (2015)

21. M. Tyulenev, Yu. Lesin, O. Litvin, E. Maliukhina, A. Abay, E3S Web of Conf., 21, 02019 (2017) 
22. A. Mallik, Md. A. Arefin, J Mech Eng Res Dev, 41(1), 156 (2018)

23. E. Makridin, S. Markov, E. Murko, Y. Lesin, M. Hellmer, E3S Web of Conf., 174, $01056(2020)$

24. O. Akuzuo, U. Eunice, I. Cynthia, Waste Water - Evaluation and Management (Croatia, Intech Europe, 2011)

25. L. D. Bernardo, Métodos e Técnicas de Tratamento de Água (Rio de Janeiro, ABES, 1993)

26. R. L. Masel, Principles of Adsorption and Reaction on Solid Surfaces (New York, John Wiley \& Sons, 1996)

27. M.T. O'Connor, K.B. Moffett, J Hydrol, 524, 15 (2015)

28. M.O. Cuthbert, T. Gleeson, N. Moosdorf, et al., Nature Clim Change, 9, 137 (2019)

29. A.A. Baratia, H. Azadi, J. Scheffran, Agr Water Manag, 221, 502 (2019)

30. T.A. Tyuleneva, Journal of Mining and Geotechnical Engineering, 1(12), 4 (2021)

31. D. Hann, J. Žarn, M. Markič, Acta Montanistica Slovaca, 25(3), 324 (2020)

32. D. Marasova, V. Zolotukhin, L. Ambrisko, International Multidisciplinary Scientific GeoConference Surveying Geology and Mining Ecology Management SGEM, 19(1.3), 57 (2019)

33. A.B. Lolaev, K. K. Khulelidze, V.V. Butyugin, A. S. Badoev, Sustainable development of mountain territories, 9(3), 283 (2020)

34. S. Markov, M. Tyulenev, O. Litvin, E. Tyuleneva, E3S Web of Conf., 15, 01011 (2017)

35. V. Zolotukhin, E. Stepantsova, M. Kozyreva, A. Tarasenko, A. Stepantsov, E3S Web of Conferences, 15, 04014 (2017)

36. T. Gvozdkova, E. Kuznetsov, A. Rudakova, S. Markov, E3S Web of Conf., 15, 01008 (2017)

37. S. Markov, Ju. Janočko, M. Tyulenev, Y. Litvin, E3S Web of Conf., 105, 01021 (2019)

38. A. Belkov, V. Zolotukhin, N. Zolotukhina, N. Sedina, M. Kozyreva, E3S Web of Conferences, 134, 03005 (2019)

39. A. Strelnikov, S. Markov, L. Rattmann, D. Weber, E3S Web of Conf., 41, 01003 (2018)

40. V. Murko, A. Zaostrovsky, E. Murko, M. Volkov, E3S Web of Conferences, 41, 01040 (2018) 